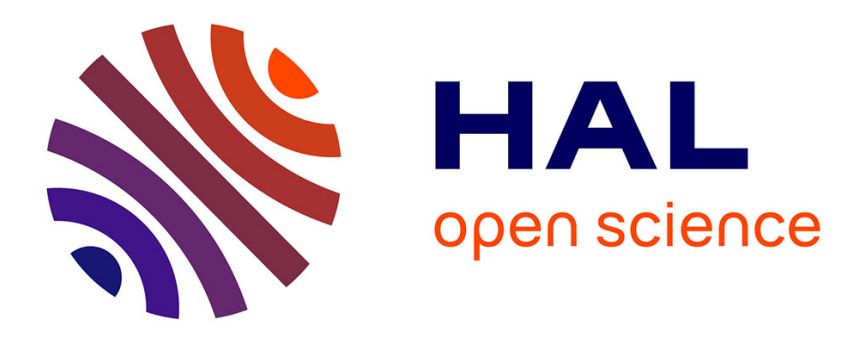

\title{
Editorial: Research on Waste and Biomass: Multiple Valorization Schemes for Progress
}

Ange Nzihou

\section{To cite this version:}

Ange Nzihou. Editorial: Research on Waste and Biomass: Multiple Valorization Schemes for Progress. Waste and Biomass Valorization, 2010, 1 (2), p.175-176. 10.1007/s12649-010-9027-5 . hal-01634022

\section{HAL Id: hal-01634022 \\ https://hal.science/hal-01634022}

Submitted on 1 Mar 2019

HAL is a multi-disciplinary open access archive for the deposit and dissemination of scientific research documents, whether they are published or not. The documents may come from teaching and research institutions in France or abroad, or from public or private research centers.
L'archive ouverte pluridisciplinaire HAL, est destinée au dépôt et à la diffusion de documents scientifiques de niveau recherche, publiés ou non, émanant des établissements d'enseignement et de recherche français ou étrangers, des laboratoires publics ou privés. 


\title{
Editorial: Research on Waste and Biomass: Multiple Valorization Schemes for Progress
}

\author{
Ange Nzihou
}

There is an increasing awareness that biomass and waste are valuable feedstocks for second generation biorefining, by-products and material production processes that give rise to platform chemicals to substitute petrochemical resources. Following the trend observed previously, this second issue of the journal presents very diverse research experiences addressing the valorization of biomass and waste related to various fields of engineering science.

Biomass is particularly concerned. Kwapinski et al. described the physical properties and compositions of biochars produced during the pyrolysis of various biomass such as miscanthus, willow and pine from 400 to $600^{\circ} \mathrm{C}$. The results showed that the surface area of the miscanthus biochar was greatly increased and nuclear magnetic resonance (NMR) spectra showed the disappearance of the carbohydrate and lignin plant components. The important issue of standards to evaluate the acceptable compositions of biochars that can be used when the products are added to soils is discussed. Fiori and Florio propose a study on gasification and combustion of Grape marc, a biomass waste of the vine-making and distilling industry, that is produced in huge quantity worldwide. Its reutilization could allow reducing disposal problems and obtaining useful by-products such as polyphenolic compounds and grape seed oil or energy. The research presented is focused on the study for alternative processes to exploit the grape marc as a source for energy. Three different process schemes have been analyzed and modeled by means of Aspen PlusTM software. The schemes investigated are Combustion process for energy production, Grape marc

\author{
A. Nzihou ( $\square)$ \\ Ecole des Mines d'Albi-Carmaux, Albi CT Cedex 09, France \\ e-mail: ange.nzihou@mines-albi.fr
}

gasification using air as oxidizing agent, Grape marc gasification using steam as oxidizing agent in a fluidized bed.

Optimization of the efficiency of processes and modeling are approaches that are gathering a significant research effort. So, Chakraborty and Banerjee have investigated a method for maximization of biodiesel yield from used frying soybean oil containing high free fatty acid. Multivariable statistical correlations capable of predicting fuel properties as a function of operating variables have been established. Inter-relations among important fuel properties of the combined-biodiesel have also been presented. Twostep process viz. acidic esterification (chemical-pretreatment) and alkaline transesterification have been considered to increase overall yield of quality biodiesel from used frying soybean oil and efficient waste management. Piccirillo et al. reported about an effective way for valorization of agriculture waste (Ginja cherry plants), and producing valuable compounds. The results have shown that the waste from traditional cherry liquor production can be used to extract antibacterial species, since the ethanolic extracts from both stems and leaves of Ginja cherry plants were rich in polyphenols. These compounds have shown an antibacterial effect.

Various experiences on the valorization of waste are also presented. Vasquez et al. have investigated the extraction of polyphenols from a waste product from the food industry, the shell of the chestnut fruit. It was examined with the aim of analyzing the potential of the extracts for the formulation of wood adhesives, for leather tanning and as natural antioxidants. Chestnut shell extracts showed total phenols contents higher than those obtained for other similar lignocellulosic materials and high values of the antioxidant activity. On experience from Ireland, Zhao et al. discussed an approach for beneficial reuse of alum sludge in engineered wetland (EW). The study aimed 
at exploring the potential of the intended purposes in the newly developed dewatered aluminum-water treatment sludge (Al-WTS) based EW for wastewater treatment. The main advantages of the proposed process are the low energy requirement and the possibility for treating and reusing a wide variety of wastewaters. Caroca et al. have discussed the platinum recovery from spent catalyst converters. The work presented comprises two steps, the leaching and ion exchange extraction (using aqua regia) with synthetic resins. The results have shown that the temperature is a very important parameter: higher temperature during acid leaching led to a better dissolution of Platinum. Most importantly, the catalytic activity tests involving both soot and the oxidation of $\mathrm{NO}$ to $\mathrm{NO}_{2}$ were performed with $\mathrm{Pt} / \mathrm{Al}_{2} \mathrm{O}_{3}$ samples derived from recovered platinum and fresh platinum. These tests showed that the recovered platinum had very similar performance characteristics as the fresh Pt.

The two following valorization experiences deal with the use of waste and biomass in civil engineering. Thus, Conrado $\mathrm{S}$ Rodrigues et al. have investigated rice husk ash as a supplementary raw material for the production of cellulosecement composites with improved performance. It has been shown that incorporation of rice husk ash in the composites did not impair the bending strength and stiffness of the developed composites and improved their interfacial adhesion strength. With a lower permeability and higher interfacial adhesion strength, the composites with rice husk ash present improved durability, considering the main deterioration mechanisms in cellulose-cement composites. Another experience is presented by Hannawi et al. investigating the effect of thermoplastic aggregates incorporation on physical, mechanical and transfer behavior of cementitious materials. The results of this study show the feasibility of the recycling of PET plastic materials as aggregates in cementitious materials. These new composites have low specific gravity, high level of sound insulation, relatively weak thermal conductivity and significant ductility. This is an interesting case because the use of plastic waste in concrete to develop new construction materials is valuable for both the construction and the plastic recycling industries.

Two last research experiences published in this issue are related to Municipal Solid Waste (MSW). Aubert et al. discussed the mineralogical characterization of MSW fly ash phases to be used as road base materials after a stabilization step to reduce the leachability of the heavy metals. The stabilization is performed using phosphoric acid to generate apatite-like phase in which the metal species are incorporated and stabilized. Rada et al. have discussed the bio-drying role in changeable scenarios of Romania MSW management. This paper shows a method useful for supporting decision makers in comparing different scenarios of waste management. It is explained that the bio-drying process was chosen for the Romanian casestudy because the Romanian MSW has a very low lower heating value and a high moisture content. A general result that comes from this study is that, the higher the energy content concentration obtained by pre-treatments, the lower is the mass available for the thermal treatments. The presented approach can be adopted also for other countries where the characteristics of MSW are known with adequate details.

The multidisciplinary and richness of the contributions presented in this issue will be confirmed in the forthcoming issues in preparation. We hope authors and readers alike will benefit from the broad range of topics covered in the Journal. Every effort will be made to encompass all aspects of science and engineering that help solve today's and tomorrow's challenges. Authors are encouraged to submit their best results so that Waste and Biomass Valorization remains the first and leading journal in this rapidly evolving field. 